\title{
Parivar Raj (Rule of Family): The Role of Money and Force in the Making of Dynastic Authority
}

\author{
$\underline{\text { Lucia Michelutti, }}$
}

\author{
Accepted July 2018 - Studies in Indian Politics
}

\begin{abstract}
This article explores the making of a political dynasty in action in a district in western Uttar Pradesh. The founder of the dynasty is a dabang: a self-made violent political entrepreneur. It is argued that the figure of the dabang offers a special ethnographic entry point to contrast forms of power that are achieved versus forms of power that are acquired (inherited) and examines the existing tensions between paternalistic and autonomous models of power. Importantly, such exercise highlights the challenges that dabangs have in cultivating their individual charismatic authority and simultaneously establishing their Parivar Raj (rule of family) by using force and money. On the whole, the presented case study helps us to reflect on the very diverse ways in which dynasties form and work according to the type of authority that is passed through generations.
\end{abstract}

\section{Background}

It is 'Mulayam Singh's Parivar Raj'. It is not a caste party, it is a family racket. Everybody agrees with this.... The problem is that it is a badly organised racket. There is no strong leadership. We are governed by four and a half Chief Ministers: Mulayam Singh Yadav (Akhilesh's father), Ram Gopal Yadav and Shivpal Singh Yadav (Akhilesh's uncles) Azam Khan, and Akhilesh is the half...

Manoj Yadav, shop owner, 65 years old

You see ... Mayawati was alone - she has no family, no sons or daughters, no uncles! And she just took the money for herself and to build statues, but there are at least 20 relatives in Mulayam's family who occupy elected state and national assembly seats - and hundreds of them at the local level, all of whom feel entitled to loot the state for as long as the SP stays in power.

\section{Rattan Singh, milk seller, 35 years old}

Talk about the power of political-business families, and more about the relation between kinship, authority and corruption is pervasive in North India. I recorded the above quotes while I was conducting research on muscular forms of politics and illegal/legal economies in a district in western Uttar Pradesh. ${ }^{-}$The Yadav family, often referred to in newspaper and TV reports as 'the firm', has been running the Samajwadi Party for the past two decades. It follows that the Yadav/Samajwadi party rule was often described as a Parivar Raj (rule of family), as the quote above indicates. Often local parivar forms of governance are associated with Goonda/Mafia Raj (rule of mafia/gangsters), popularly described as systems of political and economic governance where politics, money and crime have developed symbiotic relations. It should be 
noted that despite the comments above and widespread distrust in the state institutions and their incapacity to provide justice both Manoj and Rattan voted for the Yadav Parivar Raj in the 2014 Lok Sabha and 2017 Vidhan Sabha elections explains:

Only Yadav leaders can protect us ... we voted for Netaji (a.k.a Mulyam Singh Yadav). Mai Yadav hun. Mulayam Singh Yadav hamari naak hai, (which literally means "I am a Yadav. Our nose is Mulayam Singh Yadav").

Nose symbolizes status, prestige and power. The Hindi expression also hints at common links of substance between the representative and the represented. These entanglements of statehood and kin reveal India's rich taxonomy of electoral representation and the power of genealogies and blood. In this corner of the world, ideologies of descent, sacred lineages and widespread notions of divine kin(g)ship contribute to creating extraordinary 'politicians' and 'charismatic followers' by fashioning intimate links between them and their caste/community and kin (Michelutti, 2014). Caste modes of relatedness are, however, not static: they thicken or get thinner mirroring changes in kinship (and authority) normative foundations. In 1977, Sudhir Kakar pointed out how authority relations in the Indian family provide a template for the functioning of most modern business, educational, political and scientific organisations, and that shifts in this established paternalistic model of leadership were bound to occur only when relations of authority between father and son were challenged. In this regard, the rise and fall of the Yadav Parivar Raj illustrate some of the tension between paternalistic and autonomous styles of authority in contemporary India. In 2017, the rift between the party founder Mulayam Singh Yadav, his brother Shiv Pal Yadav and his son Akhilesh Yadav has entertained the region and the nation and opened up discussions about authoritative models and leadership capacities. The press, social media and TV described the Yadav family feud using images from the Mahabharata. The father, Mulayam Singh Yadav, fought to keep his role as the party's leader. In the end, Akhilesh seems to have 'won the war' with his father and uncle, and he is now the party boss. Akhilesh, independent from his father, now has autonomous authority. His personal struggle for independent leadership mirrors the myth of the authoritative strong leader - a template that has become quite popular over the last decade in western Uttar Pradesh.

It is not a coincidence that during the 2017 election campaign, at the heart of the Yadav family dynastic rift, two videos featuring Akhilesh as a 'boss' were circulated and shared on social media. They feature the then Chief Minister Akhilesh Yadav in the place of actor Shah Rukh Khan as a big strongman in the Bollywood hits Raees and Don 2. One of the clips, entitled 'Akhilesh 2', featured Akhilesh Yadav acting Shah Rukh Khan's famous lines in Don 2: 'My enemies were thinking that I would never return. But I will come back' (Michelutti, 2017, p. 59). Another video clip again featured Akhilesh as Shah Rukh Khan, this time in the movie Raees, saying: 'My mum used to say no business is small and no religion is bigger than business. What is good for business is good. What is bad for business is bad.' Later, Shah Rukh Khan says that he embodies both business sense (the brain of a Bania) and daring. The video concludes with a veiled threat, Aa raha hoon (I'm coming!) (Michelutti, 2017, p. 59).

Thus, Akhilesh's struggle to be recognized as an authoritative leader shows some of the complexities of the contemporary Parivar Raj, the generational battles between fathers and sons and the ways in which dynasticism and models of succession are reinvented (and, more crucially, performed) through a variety of mediums: social media, movies, TV series, political rallies and protests. The videos that feature Akhilesh as a strongman-boss are indeed part of the permanent performance that characterizes Indian politics (Hansen, 2001). Importantly, they 
reflect the appeal of forms of 'independent' and 'achieved' authority based on action, money and glamour (Michelutti et al., forthcoming).

Increasingly in North India, leaders need to mix business with daring and project a capacity to make money, run successful businesses and make profitable deals. At its extreme this type of authority is embodied in the exceptional figure of the self-made 'violent political entrepreneur'. In the district where I conducted fieldwork, these figures are called dabang (enforcer/boss): they often combine a professional criminal career with a professional legitimate political and business career. $\underline{3}$ They use private (and state) force as a means of social control and economic accumulation. But ultimately, they are individuals 'who make themselves respected' (Blok, $\underline{1974}$, p. 38). And it is precisely because they are successful self-made men (and occasionally women) 'who ambitiously dare to take risks; manage to accumulate wealth; and build a better life for themselves, their families, their clients, and their associates' (Michelutti et al., forthcoming, p. 19) that they are admired. They are also admired '...for their determination and their claim to re-establish order ... because they appear to challenge and reject caste and class barriers, gender roles, family hierarchies, and inequalities. But it is their apparent ability to defy and escape death and be above the law that ultimately endows them with an aura of extraordinariness' (Michelutti et al., forthcoming, p. 19).

As Richard Sennett highlighted in his book Authority, personal mastery is so rare; it has auratic qualities and commands respect $(\underline{1980}$, p. 84). Dabangs certainly command respect, and they are valued for what they have achieved, not for what they are (Michelutti, 2010, p. 46; see also Piliavsky \& Sbriccoli, 2016, p. 376). As such, the figure of the dabang provides a special ethnographic entry point to capture empirically the production and management of charismatic forms of authority and contrast forms of power that are achieved versus forms of power that are acquired (inherited). Importantly, this exercise will help us to reflect on the very diverse ways in which dynasties form and work according to the type of authority that is passed through generations. Such analysis echoes classical anthropological work on kingship and big men and chiefs in Melanesia and Polynesia (Sahlins, 1963) where the big man's power lies in his actions and not his status, as well as recent debates on personal forms of sovereignty (Hansen \& Steputtatm 2005; Michelutti et al., forthcoming) and the production of leaders and followers in South Asia (Price \& Ruud, 2010). While dynasticism has been studied among different Indian socio-economic groups, for example among the forward castes (Chandra, 2016) or Tribal and SC groups (Chauchard, 2016), the dynastic attempts of a new generation of dabangs have not received attention despite their visible presence and relevance in local and regional politics for the past 15 years (Jaffrelot \& Kumar 2009; Vaishnav, 2017; Verniers, 2014). This article asks: How do dabangs establish dynasties with money and force? What type of difficulties do they encounter in systematizing their charismatic and 'achieved' authority? And ultimately what do their stories tell us about wider popular cultures of dynasticism?

I answer these questions by discussing the struggles of two young men (Vinob and Narenda). Like their former chief minister, Akhilesh Yadav, they are entering into politics to maintain and develop the power and business of their family firm. In the process, they are also attempting to carve out an independent space for themselves. The founder of this aspiring political dynasty (Vinob and Narendra's mother) is a fascinating and fearless violent entrepreneur: a high-caste businesswoman and local politician who has accrued power and wealth in an extremely violent and male-dominated corner of North India. Locals often refer to her as 'Lady Dabang'; however she likes (and often explicitly demands) to be called 'Netaji', which is an honorific term usually reserved for male political leaders. In this particular area of Uttar Pradesh, when people talk about Netaji, they are generally referring to Mulayam Singh Yadav. According to 
Lady Dabang: 'He may be the Netaji of Uttar Pradesh, but he is not the Netaji of western Uttar Pradesh; I am!' she told me, smiling, when I enquired about her title. Lady Dabang also know as Netaji does not belong to an old pre-democratic ruling class but rather is part of the new generation of self-made bosses. She gained her power through violent acts and criminal entrepreneurship. As such she came to encapsulate the mythical lure of the independent outlaw who lives on the edges of normal structures and comes to possess quasi-magical powers. In order to keep her liminal power, she needs to live up to this image and at the same time cultivate impunity by trying to institutionalize her authority through electoral dynastic performances: a very tricky task. Ticket buying and unopposed elections are among the methods through which such performances are enacted. It should be noted that winning elections is not strictly necessary to create and maintain bosses' dynastic authority and keep their businesses in profit. By contrast, I argue what are crucial are the performances that are aimed at generating successions. Performance is central to bosses' authority. Sovereign power as a project is always tentative and unstable and depends on repeated performances (Hansen \& Stepputat, 2005, p. 4). Yet dabangs' authority is 'extra' tentative because of its charismatic nature and owes much to the chronic unpredictability of the collusive arrangements among criminals, entrepreneurs, bureaucrats and politicians, typical of Mafia Raj (see also Gayer, 2014). In such environments, it is extremely difficult (and risky) for bosses to create new successors without losing the power of the self-made creator, and it is equally difficult for the successors to become authoritative in their own right. Ultimately, looking at dynastic tensions 'in action' and at the theatrics of ticket buying and unopposed elections will show how a propensity for dynastic politics is not exclusively the product of some cultural predilection for family caste-based authority but is also deeply linked to risky 'criminal' political economies, weak state institutions and polarized forms of politics.

\section{Self-made Bosses in Risky Political Economies}

Western Uttar Pradesh has undergone tremendous economic and social transformations over the past two decades. In popular national perception, the region is increasingly thought of as the Sicily of North India. The region is widely known for its endemic violence, for being culturally shaped by the 'macho' ethos of its dominant castes, such as Jats, Yadavs, Gujjars and Thakurs, and for being marred by communalism and caste-based conflicts. Available statistics and sociological studies have defined this area as the cradle of 'a subculture of violence' and the home of 'institutionalized riot systems' (Brass, 1997, 2003). However, what is perhaps deeply misleading is the portrayal of this region as a poor provincial backwater. On the contrary, this is a land where, over the past decade, fortunes have been made in one generation and where upward mobility and entrepreneurship are fully entrenched in the imagination and fantasies of the younger generations.

Over the past 10 years, traditional specialists in violence stopped supplying their services to the big leaders: they stopped acting as mercenaries for their landlords and patrons and instead began to use their muscular skills to stage a better life for themselves and their families and create their political mafia-esque clans (Michelutti, et al., forthcoming). They are some of the main characters of what is described as the 'criminalization of Indian politics': a world where muscle and crime (violent and non-violent) both play in the political arena (Vaishnav, 2017) and in business (Harris-White \& Michelutti, forthcoming). ${ }^{4}$ In 2017, the Bharatiya Janata Party (BJP) won the elections, and in the new assembly, 143 (36\%) of 403 elected MLAs have criminal cases against them. Importantly, 80 per cent of the winning candidates are multimillionaires. Thus, in the latest election multimillionaire and/or 'criminals'/ businessmen were the main protagonists once again. In western Uttar Pradesh, it is often real estate and 
forms of predatory property accumulation that create the most profitable opportunities for bosses. Land and property transactions are opening up new career paths that require the capacity to handle coercion, manage extra-legal activities, and above all, play the game of politics. A trend emerges from the data I collected by following the lives of six local dabangs and aspiring dynastic founders: (a) bosses gain authority and a monopoly on a territory through violence and money (mainly by acting as an enforcer); (b) they enter into politics and acquire democratically elected authority and (c) they try to form a political dynasty in order to secure authority and wealth for their family but not without difficulty. Today the district is populated by rising stars - men (and occasionally women) in their 30s and early 40s who are using 'criminal capital' to enter into politics to protect their businesses (Hoque \& Michelutti, forthcoming). Thus, Lady Dabang is not alone. Competition is fierce. Basically, bosses run protection rackets with the advantage of democratic legitimacy and all the glory and prestige that comes with being a legitimate 'little king' or 'little queen'. They enter into politics to make money or to protect businesses and make more money and, perhaps more importantly, to gain respect. Lady Dabang often mentioned how poor people have very few chances of becoming rich and that politics and muscle were the only tools available to her to become 'someone'.

It should be noted that these are settings where criminal bosses can enter directly into politics because there is a demand for them and because they have the money to do so. .5 Many years ago, Gambetta (1993) argued that lack of trust in a context where the state is unable to provide basic security generates the popular demand for mafia-like protection. In the case of western Uttar Pradesh, it is not only a lack of confidence in the government (although it undeniably exists) that provides a 'robust pillar for mafia business' but also local animosities and conflicts between and within communities provide fertile ground for bossism to prosper (Martin \& Michelutti, 2017). In a world where 'the rule of law' is visibly absent, politics is polarized and economic crime shapes everyday lives, people are increasingly taking refuge in their families, friends and 'their' blood-related bosses. Elected dabangs become guarantors of provision of protection and often share kin or fictive kin relations with the people they 'protect'. This should not be seen as an expression of 'amoral familism' - a concept developed by the political scientist Edward Banfield (1958) to explain 'familial societies' where alliance to one's family interests occludes any consideration of interest in the wider public. This framework has been used to explain 'the crime clan' phenomena and mafias in 'backward' South Italy and was heavily critiqued (Pine, 2012, p. 11). Instead, what we are witnessing in western Uttar Pradesh is effectively a 'comprehensive and efficient manifestation of modernity, and one possible way of interpreting politics [and authority] in times of globalisation' (Armao, 2015, p. 4). India is yet another established democracy in which intense electoral competition combined with predatory forms of capitalism is producing particular forms of family mafia politics. ${ }^{6}$

\section{Protecting 'the Family Firm'}

Importantly for the argument that I make in this article, Mafia Raj are environments that are inherently 'fraught with uncertainty, distrust, suspicion, paranoid anxiety and misunderstanding' (Von Lampe \& Johansen, 2003) because illegality and competition are pervasive. Micro-level illegal/legal economies and local 'mafias' are central to the individual careers of dabangs and also to the lives of the people living in their territories. ${ }^{7}$ As scholars of organized crime and mafia-like enterprises show, there is a need to minimize mistrust in environments where illegal activities and violence are central to the local economies. 'Institutional safeguards designed to compensate for the consequences of deceit and betrayal, such as courts and insurance, are of course unavailable for illegal actors' (Von Lampe \& Johansen, 2003, p. 1). In the literature it has been established that the consequences of disloyal 
behaviour in illegal spheres are far greater than those to be expected in the legal sphere of society. Accordingly, trust embedded in kinship/caste bonds should be treated as an essential coping mechanism to control risk in Parivar Raj forms of governance. ${ }^{8}$ A local kingmaker well exemplifies it: 'I can't further enlarge our firm [he runs a very successful construction company] because expansion means the involvement of workers from outside the family and one can't trust outsiders in our business.' This comment aptly exemplifies the fragility and potential volatility of political-criminal configurations (Gayer 2014, p. 134). Dabang firms are loosely organized in 'concentric circles' of power. ${ }^{-}$In the district under study, people talk about 'small mafia' and 'big mafia'. To elaborate further, the Indian term 'mafia' is locally employed to refer to business enterprises with political protection that seek to monopolize particular trades, sectors and localities through extra-legal and violent means (as in the cases of 'alcohol mafia', 'water mafia', 'oil mafia', 'coal mafia' or a variety of 'land grabbing' practices by the 'land mafia'). Such syndicates protect clients and cronies and work simultaneously against and in tandem with local politicians, the justice system and the bureaucracy. Local expressions such as 'company', 'lobby', 'firm' or 'racket/cartel', parivar (family) or 'groups' or 'rings' can locally describe anything from a protection racket to a power syndicate, a violent lobby/interest group or a handful of ambitious criminals working as part of a team. In these companies, the boss is often surrounded by a circle of about 20 or 30 young people who are often derogatively known as chamchas (sycophants). These young men (rarely are women involved) need to show courage, reliability and devotion to their boss. Bosses are then surrounded by a trusted inner circle, which is formed mainly by family and kin. A further circle is composed of gunmen, musclemen and their crew, moneylenders and businessmen and government administrators who know that they are dealing with a dabang's company but do not know how the company works internally. Finally, there is a further protective circle at the level of the territory that the boss is actually de facto governing or aspiring to control. The reputation and operations of dabangs are territorialized. The boss relies on the complicity, collaboration and silence of the local population. In these 'territories', dabangs are often called bhai or dada (brother) and their racketeering is often normalized in the language of kinship, family and izzat (honour). It should be noted that this is not specifically a North Indian phenomenon as the usage of terms such as 'godfather'/padrino clearly indicates. Such language metaphorically suggests nurturing and caring for the others. It is deeply embedded in strong paternalistic/lordly styles of authority that are used to justify the legitimacy of power by showing interest in others and in the public good.

However, these circuits of protection and ideologies of patronage are fragile and contested. Overlapping repertoires of authority are available; bosses are not the only authority in a given context, and people pay their dues to several at the same time. The position of boss is perpetually insecure, even among their kin. Bosses live in constant fear. They fear losing their position, their money and their power. They continuously have to look over their shoulder to guard against ambitious young men and henchmen (Michelutti, et al., forthcoming; Picherit). It should also be noted that while bosses try to minimize risks by employing family members, they also thrive on instability and often make a virtue out of it. Uncertainty, if well-staged, has the capacity to spread paranoia and enhance the magnitude of bosses. Thus, the cultivation of insecurity becomes an integral part of the charismatic power of the boss. It is in these unstable but opportunity-rich arenas that bosses' dynasties are performed.

\section{The Theatrics of Ticket Buying and Unopposed Elections}

For a start, the survival and prosperity of dabangs' businesses depend on a negotiated lack of law enforcement. State and national elections can trigger changes in who protects who. In order to protect both their illegal and their legal activities, local bosses need to use money and 
violence to be active in the political, judicial and security systems of the country. This process involves deploying 'trusted' relatives in business, 'criminal' and political activities. During election campaigns, the main aim of these formations is to do whatever is possible to maintain the integrity and continuity of their businesses. And it is with this in mind that they strategize how to manipulate the electoral process and/or even how to reposition themselves in the middle of the election campaign if necessary. Some of the bosses contest elections directly, some push sons or daughters to contest, some provide support through money and muscle for local candidates and some support more than one candidate. This is an area where switching political parties is extremely common and widely accepted. Self-sabotage is also a well-rehearsed technique. As a local dabang explains:

There are two types of candidates in any election. The ones who run to win ... and the ones who run to make a profit.... In this constituency dabangs run to make a profit and help 'clean' candidates to win by selling them votes... You keep the money allocated for the election campaign and you make more money by selling votes from your protected areas to the two main contending candidates. This is a business strategy. $\frac{10}{}$

This is the business strategy followed by Netaji. Such deals are usually made very close to the election day and are also very effective ways of negotiating impunity with the newly elected government. Profit and business decisions are what move this world. Electoral positions are bought and traded. In the available literature, much of the attention is focused on vote buying and trying to understand if this practice translates into electoral victories or not. $\frac{11}{}$ However, what is often left unquestioned are the 'criminal/illegal' origins of the vast sums of money that are used in politics. In addition, we all too often neglect to do an empirical examination of a very widespread 'open secret'; that political positions can be bought and sold, and are often offered to the higher bidder. As Vaishnav sums up, ticket buying is 'a common practice carried out by most political parties...; what differs is the extent to which parties acknowledge its use. For example, Mayawati, the former Chief Minister of Uttar Pradesh and president of the BSP, is quite open about the expectation that prospective candidates should make a hefty contribution to the party in exchange for nomination' (Vaishnav, 2017, p. 218; refer also to Sircar, 2018). Money-rather than muscle -seems to increasingly provide dabangs with opportunities to enter active politics. However, criminal candidates are also increasingly unable to contest MLA and MP elections because their criminal records are much more under scrutiny from the press, political parties and the electorate. The response to this is to put forward sons, relatives or wives. This has certainly been the case since 2013 when the Supreme Court banned people convicted of serious crimes from holding office. This is the path allegedly taken by Netaji. The capacity for ticket buying and staging unopposed elections contribute to expanding her power. Netaji's reputation is based on violence, daring and business skills. It is crucial to remember that dabangs are often objectified by the law as 'criminals', and they use this reputation to establish their authority. It is often not in spite of criminal accusations that they are popular but rather because of such charges and/or allegations (Michelutti et al., forthcoming). Being suspected of murder is an accolade for Lady Dabang, not a stigma. It provides hard-to-fake evidence that she is 'bad', and it spreads knowledge of this trait. In a similar way, ticket buying and unopposed elections provide tangible evidence that one is powerful and influential and has the money to be a self-financed candidate. The stories of Vinob and Narendra show that voters think that politicians need to be very influential and rich in order to impose a son or a daughter on a party. Being able to buy tickets (rather than simply winning the election, as is often assumed, or being able to buy votes) greatly contributes to expanding the authority of dynastic founder. It signals a leader' access to powerful state and national networks and a capacity for violence. 


\section{Being the Son of a Dabang and Contesting Elections}

Netaji's sons did not enter into politics regardless of their mother's activities. They entered precisely because they were sons of a boss and, importantly, because they were required to and had the money to. They were introduced into the business of politics to spread their parivarfirm power across a larger territory, to minimize risks and protect family members' impunity and, above all, to ensure the present and future wealth of the family firm.

Take, for example, Lady Dabang's younger son Vinob who was pushed to contest 'unopposed elections', was eventually elected Block Pramukh and later on a member of the Zila Parishad (ZP). Elected posts like Block Pramukh or being a member of the ZP are key powerful (both politically and economically) posts in the locality. These low-level political battles are often overlooked by studies of dynastic politics in the subcontinent. This is quite remarkable since the power struggles for these posts is often violent and costly precisely because these posts (e.g., the ZP office) often wield substantial power. The importance of ZPs lies in the fact that they are a point of convergence for local politics, economic institutions and the bureaucracy or the main institution that links the state with the local. $\frac{12}{}$ It should be noted that the chairman of the ZP is also the head of the District Board, of which all the ZP members, MLAs, MPs, MLCs, Block Pramukhs, Gram Pradhans are members. Controlling the ZP means keeping a check on economic and political competitors on the rise. This political level is also deeply informed by money. Competitors are routinely eliminated not only through violence and intimidation but with money. 'I paid off anyone running against me so that they would withdraw from the election', was a statement that I heard, time and again. Money and muscle create what is locally called an unopposed election-elections where only one candidate runs. This type of election is very much a topic of discussion in the locality. They are infused with mystique and drama. They are the source of endless gossip. They are transgressive acts that provoke a mix of admiration and fear and are an integral part of the local folklore and self-mythologies of dabangs. Lady Dabang's son's unopposed election has been recounted to me a myriad of times. I also happened to overhear numerous spontaneous conversations about it. Each time I heard the story, new details were revealed, added, magnified or invented. One needs to be powerful and influential in order to stage unopposed elections. People spent hours speculating about the millions of rupees that were necessary to eliminate competition. They recounted how candidates were kidnapped and/or coerced to prevent them from filing nominations. In the end, these multiple narratives and their performances in everyday talks become part of the spectacle that shapes Netaji's capacity to command respect. But what did Vinob have to say about it?

To start with, Vinob was not particularly interested in entering politics despite growing up in a political family. To win his seat he did not have to deploy any political skills or do any campaigning as the election was, as he proudly said, 'unopposed'. 'Nobody filed a nomination against me. No one stood against me' he said. I asked why. Were there no other candidates? 'Because I am powerful (well my mum is) and nobody dares to compete against me (with her),' was his answer. Of the two brothers, he is the one that embodies the local dabang aesthetic: he wears dark sunglasses and leather jacket, travels in big cars and sports expensive jewellery. He said that when he was growing up he met the big leaders and party workers who came to visit Netaji. He boasted that he had met Mulayam, Mayawati, Raj Babbar and the late Phoolan Devi. In our conversation, however, he was always quite adamant about how much he hated politics. According to him, nobody can become a politician without telling lies. He admired his mum for being so successful and having built a career out of nothing, and out of respect for her (and fear I suspect), he agreed to join politics after he got married. He recalls how Netaji started her career in the Samajwadi Party and then moved to BJP and BSP. Vinob said proudly that Netaji 
contested elections for chairman as an independent candidate several times and finally managed to win after three attempts. He said, 'She never gives up ... contesting as an Independent shows real strength.' For Vinob, Netaji is a hero: 'She is the local Phoolan Devi.' Lady Dabang's sovereign power is indeed deeply shaped by the figurative power of Phoolan Devi also known as the Bandit Queen - one of the icons of North Indian low-caste politics and Indian feminism. I first met Lady Dabang when she was at the start of her impressive career about 20 years ago. At that time, she was introduced to me as the emerging local 'Bandit Queen'. So Vinob is not the only person who makes such connections. Phoolan Devi was a dacoit and criminal politician from a lower caste. In 1996, she won elections in western Uttar Pradesh and was a sitting member of parliament when she was assassinated by rivals in 2001. Over the past 15 years, Phoolan Devi has become a heroine-goddess, achieving international status through numerous biographies, movies, theatrical performances, comics and video games. $\frac{13}{}$ Like Phoolan Devi, Netaji's local self-mythology began with her taking revenge for a gang rape and her struggle against caste and class social injustices. Like Phoolan Devi, she portrays herself as the protector of the poor and marginalized, and she entered into politics and won elections. Thus, through the myth of the Bandit Queen, Netaji is in constant dialogue with authoritative 'fictional' cultural exemplars that exalt what Eric Hobsbawm (1969) has characterized as 'social bandits' or 'men (women) of honor'. Vinob cannot inherit such an aura, and he is very aware of it. He says that he shares with his mother a capacity to mingle with poor people and to make contacts with lower caste and disadvantaged communities. In particular, he has good friends among the local Valmiki communities (a Dalit caste) and this was helpful when Netaji joined BSP. However, he does not think he is authoritative. When Vinob joined politics, he said that he felt very inadequate and with no skills, and it was Netaji who took care of everything.

She said she would help me out and teach me all the necessary tactics. She also said that she would take care of everything and that I did not have to worry.... At the beginning after being elected I was terrified to go to office. I was very nervous. I felt I did not have authority and I did not have any idea of what to do. The first year has been hard but now I can manage, and I like politics a bit more. However it hurts me that I need to lie to poor people. One needs to lie in order to survive in politics....

Vinob's face lights up when we moved the conversation from politics to the real estate development business his family firm runs. Business is obviously what he likes to do. However, also in this sphere of his life, Netaji is the boss: 'She does the big deals. I just follow small acquisitions.'

In contrast, the older brother, Narendra, has been groomed to be a politician and pushed to run for MLA and MP elections. Netaji always eagerly talked about him as 'the gifted son'. She often remarks how people take to him easily, and she is convinced that in the long run he will do well. She acknowledges that he is still young and needs to learn but being young is to his advantage and will allow him to attract the vote of the youngsters. More importantly, he will be able to contest Lok Sabha elections as he is 'clean' with an unsullied image. Unlike his brother, Narendra dreams of a political career. He likes to be a proper politician and be able to give speeches at big rallies and serve the people. He spends hours in front of the mirror rehearsing speeches. He thinks that giving good speeches is an indication of how good a politician is. To master the art of public speaking is, for him, what real politics is about. He thinks that a candidate needs to be a confident speaker to have a chance of winning. He often eagerly showed me his latest speeches that he carefully records with his iPhone. Overall, Narendra is very organized and conscientious and works hard to project an image of the clean, 
honest and lordly politician. A few years ago, Narendra contested state and national elections. In neither cases was he chosen by the party based on his abilities but rather because of Netaji's authority and her economic clout in the area. She allegedly bought him the party tickets for several million rupees. He did not win, but as one of the family lawyers remarked: 'We still made lots of money.' Certainly, Netaji thinks of politics mainly as a profit-making investment rather than in terms of good speeches and political oratory. Making money (and maintaining authority) does not necessarily mean winning elections; simply participating is often enough. Running for office ensures being known, prestige and a place on the local political map; it shows followers that you have the money to run and signals to rivals that you are on the scene. Local strongmen know very well that by being a protagonist in an electoral contest, they make themselves visible. To navigate the violent competition for economic and political resources, bosses need to pay attention to electoral positions and to the building of compromises and alliances, and this process involves performing dynasticism. In many ways elections and the theatricals - spectacle and media attention - that they provide become an integral part of the dabangs' local dynastic authority. Lady Dabang knows this all too well, and Narendra and Vinob have become tools both to minimize risks in illegal business and simultaneously to cultivate and manage her local authority. With such constraints, Vinob and Narendra are still not able to carve an independent political career for themselves, not yet. Narendra may give good speeches but lacks the necessary authority to rule-which is still provided by Netaji. The locals often point out: 'He doesn't have the balls.' His authority is dependent on the willingness of his mum's 'family firm' members to follow his orders. Ultimately, Netaji is still the boss.

\section{Concluding Remarks}

Vinob and Narendra always call their mother 'Netaji'. This is an interesting fact in itself as the use of the title seems to symbolically break kinship/filial ties. This is a process that is wellknown in studies of kingship. As Quigley well exemplifies:

...Being set apart is the very crux of kingship, a leitmotif marked by the recurrence of a set of rituals that allow an individual to be extracted from the kinds of economic, political, and kinship relations that bind 'ordinary' people, and made into a person (or nonperson) who is literally extraordinary - outside conventional society - through the cultural device of an installation ritual. (Quigley, 2005, p. 4)

Netaji is set apart from the ordinary by managing dangerous worlds and mastering her personal sovereignty. Hansen and Verkaaik point out that such individuals are 'akin to the traditional healer or diviner who interprets a dangerous and powerful natural world but violates taboos in order to do so. A powerful charismatic figure is also allowed to break taboos as long as he/she can perform the key function of interpreting the present and giving a direction amidst an unknowable and ostensibly dangerous environment.' (2009, p. 8).

And it is precisely this 'uniqueness' and extraordinary character of 'Netaji' that make the production of dynastic authority quite problematic. This is because maintaining boss authority often entails consciously sidestepping what Weber (1978) famously called the 'bureaucratization of charisma'. In order to preserve liminal power, Netaji needs to live up to her violent entrepreneurial image. By the same token, she also needs to cultivate impunity by attempting to institutionalize her power with the help of her sons. Such performances remind us that certain forms of power do not self-perpetuate easily through kinship. They also show that it is not only the nature of party organization and competition that shape succession (Chhibber, 2011) or the character of the Indian state and 'the high returns to state office' 
associated with it (Chandra, 2016, p. 12) but that also depends on the type of authority that is supposed to be passed on and maintained through time. Thus, the key question that needs to be posed when exploring succession practices in democratic politics is as follows: What type of authority is dynasticized? In order to do so it is necessary to map out the cultural values and appeal imputed to different forms of power, achieved versus acquired, and the ongoing tensions between paternalistic and autonomous 'charismatic' styles of power. Commenting on the latter forms of authority, Sennett $(\underline{1980}$, p. 27$)$ compellingly argues that in the modern age, 'the independent ones' are people who are able to command respect. These are autonomous figures who, contrary to their paternalistic predecessors, do not have to express (or pretend to) care for others to obtain power. These are leaders who are given power even if their legitimacy is called into doubt. Understanding such authoritative models is increasingly important, given that we live in a world where self-made strongmen-business tycoons with political ambition are increasingly popular, win elections and attempt to create political dynasties, and the anthropology of authority and dynasticism can help us to do so.

\section{Declaration of Conflicting Interests}

The author declared no potential conflicts of interest with respect to the research, authorship, and/or publication of this article.

\section{Funding}

The author disclosed receipt of the following financial support for the research, authorship, and/or publication of this article: Research for this article was conducted within the framework of the research programme 'Democratic Cultures' (http://www.ucl.ac.uk/democratic-cultures), which explored the overlap between criminal cultures and politics across India, Bangladesh and Pakistan (funded by the following grants: ERC-AIMSA/284080 and ESRC-

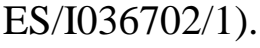

\section{Notes}

2.Throughout the text, I have changed the names of people and places to ensure their privacy and safety. In addition, I changed some of the characteristics of participants (such as age/occupation) to further conceal their identities. Ethnographic data was collected by direct observation, conversations and interviews in a provincial town in western Uttar Pradesh during 12 months of fieldwork between March 2012 and June 2016.

3.In the text, I use the terms 'boss' or 'dabang' interchangeably. On violent entrepreneurs refer to Blok (1974), Sidel (1999, pp. 71-72) and Volkov (2002).

4.By 2002, almost 50 per cent of political candidates in Uttar Pradesh had criminal charges registered against them or were under investigation. Criminal candidates won 206 of 403 seats, an absolute majority of 51.1 per cent, and earned for SP, which governed the state between 2002 and 2007, the title of 'Goonda Raj'. The 2007 election to the Uttar Pradesh State Assembly marked the end of the SP's rule and the rise to power of the rival BSP. Contrary to what many had hoped for, this election was no less criminalised. Indeed, in 2007, the number of criminal candidates from both parties increased, and the winning BSP fielded the highest proportion of criminal candidates (34\%). The SP returned to power in 2012. Despite a vocal 
anti-criminalisation campaign launched by the Election Commission and several civil society groups (including the Anna Hazare movement), a total of 189 legislators (47\%) of the newly elected State Assembly had criminal charges pending against them (according to the affidavits they were now required to file by the law). It should be noted that in the area under study, the most 'criminal' politicians did not appear in these statistics because nobody dares to file a case against them.

5.On the cost of Indian democracy and self-finance candidates refer Sircar (2018).

6.Refer, for example, for Jamaica (Jaffe, 2013), for Italy and Mexico (Armao, 2015), Russia (Volkov, 2002); Latin America (Arias, 2016), Indonesia (Wilson, 2015).

7.On the concept of 'territorial democracy' and violence during local level elections refer Witsoe (2009).

8.Refer, for example, the literature on organised crime where trust is treated as a feature of mafia-like enterprises (Paoli, 2003, p. 84).

9.A similar 'concentric' organisational structure is described by Letizia Paoli in the case of Cosa Nostra and Ndrangheta (2003, p. 106).

10.Cited in Michelutti, et al., forthcoming, p 174.

11.For a summary of the literature refer Bjorkman (2014).

12. One of the few available studies on ZP is an unpublished master's dissertation by Rajkamal Singh (2016).

13.On the myth of the 'Bandit Queen' refer, for example, Assayag (2006) and Seal (2009).

\section{References}

Arias, E. D. (2016). Criminal enterprises and governance in Latin America and the Caribbean. Cambridge, UK: Cambridge University Press. Google Scholar

Armao, F. (2015). Mafia-owned democracies: Italy and Mexico as patterns of criminal neoliberalism. Revista de Historia Actual, 1, 4-21. Google Scholar

Assayag, J. (2006). Sur les chasses du temps. Histoire et Anthropologie chez Eric J. Hobsbawm. Revue d'Histoire Moderne et Contemporaine, 53(4), 100-113. Google Scholar, Crossref

Banfield, E. (1958). The moral basis of a backward society. Glencoe, IL: The Free Press. Google Scholar

Bjorkman, L. (2014). 'You can't buy a vote': Meanings of money in Mumbai elections. American Ethnologist, 41(4), 617-634. Google Scholar, $\underline{\text { Crossref, ISI }}$

Blok, A. (1974). The Mafia of a Sicilian village, 1860-1960: A study of violent peasant entrepreneurs. New York, NY: Harper and Row. Google Scholar

Brass, P. (1997). Theft of an idol: Text and context in the representation of collective violence. Princeton, NJ: Princeton University Press. Google Scholar 
Brass, P. (2003). The production of Hindu-Muslim violence in contemporary India. Seattle, WA: University of Washington Press. Google Scholar

Chandra, K. (2016). Why 'forward castes' have a dynastic advantage. In Chandra, K. (Ed.), Democratic dynasties (pp. 12-55). New York, NY: Cambridge University Press. Google $\underline{\text { Scholar }}$

Chauchard, S. (2016). Disadvantaged groups, reservation, and dynastic politics. In Chandra, K. (Ed.), Democratic dynasties. New York, NY: Cambridge University Press. Google Scholar Chhibber, P. (2011). Dynastic parties: Organization, finance and impact. Party Politics, 19(2), 277-295. Google Scholar, SAGE Journals

Forbess, A., Michelutti, L. (2013). From the mouth of god: Divine kinship in contemporary popular politics. Focaal-Journal of Historical and Global Anthropology, 67, 3-18. Google $\underline{\text { Scholar }}$

Freeman, L. (2007). Why are some people powerful? In Astuti, R., Parry, J., Stafford, C. (Eds), Questions of anthropology (pp. 281-306). Oxford, UK: Berg. Google Scholar

Gambetta, D. (1993). The Sicilian Mafia: The business of private protection. Cambridge: Harvard University Press. Google Scholar

Gambetta, D. (2000). Mafia: The price of distrust, Chapter 10. In Gambetta, D. (Ed.), Trust: Making and breaking cooperative relations (Electronic edition, pp. 158-175). Oxford, UK: Department of Sociology, University of Oxford. Google Scholar

Gayer, L. (2014). Karachi: Ordered disorder and the struggle for the city. New York, NY: Oxford University Press. Google Scholar

Hansen, T. B., Stepputat, F. (Eds) (2005). Sovereign bodies: Citizens, migrants, and states in the postcolonial world. Princeton, NJ: Princeton University Press. Google Scholar

Hansen, T. B., Verkaaik, O. (2009). On everyday mythologies in the city. Critique of Anthropology, 29(1), 5-26. Google Scholar, SAGE Journals, ISI

Harriss-White, B., Michelutti, L. (Eds) (forthcoming) Wild east? Criminal political economies in South Asia. London, UK: UCL Press. Google Scholar

Hobsbawm, E. (1969). Bandits. New York, NY: Delacorte Press. Google Scholar

Hoque, A., Michelutti, L. (forthcoming). Brushing with organized crime: Jugaad as democracy. Journal of Asian Studies. Google Scholar

Jaffe, R. (2012). The popular culture of illegality: Crime and the politics of aesthetics in urban Jamaica. Anthropological Quarterly, 85(1), 79-102. Google Scholar, Crossref

Jaffe, R. (2013). The hybrid state: Crime and citizenship in urban Jamaica. American Ethnologist, 40(4), 734-748. Google Scholar, Crossref, ISI

Jaffrelot, C., Kumar, S. (Eds.) (2009). Rise of the plebeians? The changing face of the Indian legislative assemblies. Delhi: Routledge. Google Scholar

Kakar, S. (1977). Authority in work organizations. Vikalpa, 2(4), 253-264. Google Scholar

Martin, N., Michelutti, L. (2017). Protection rackets and party machines. Comparative ethnographies of Mafia Raj in North India. Asian Journal of Social Science, 45(6), 692-722. Google Scholar, Crossref

Michelutti, L. (forthcoming). Lady dabang. In Michelutti, L., Hoque, A., Martin, N., Picherit, D., Rollier, P., Ruud, A. E., Still, C. (Eds.), Mafia Raj: The rule of bosses in South Asia. Stanford, CA: Stanford University Press. Google Scholar

Michelutti, L. (2010). Wrestling with (body) politics: Understanding 'Goonda' political styles in North India. In Price, P., Ruud, A. E. (Eds.), Power and influence in South Asia: Bosses, lords, and captains. Delhi: Routledge. Google Scholar 
Michelutti, L. (2014). Kingship without kings. In Piliavsky, A. (Ed.), Patronage as politics in South Asia (pp. 283-302). New Delhi: Cambridge University Press. Google Scholar, Crossref Michelutti, L. (2017). The cult of the boss. Seminar, 693, 58-64. Google Scholar

Michelutti, L., Hoque, A., Martin, N., Picherit, D., Rollier, P., Ruud, A. E., Still, C. (forthcoming). Mafia Raj: The rule of bosses in South Asia. Stanford, CA: Stanford University Press. Google Scholar

Paoli, L. (2003). Mafia brotherhoods: Organized crime Italian style. Oxford, UK: Oxford University Press. Google Scholar

Piliavsky, A., Sbriccioli, T. (2016). The ethics of efficacy in north India's Goonda Raj (rule of toughs). Journal of the Royal Anthropological Institute, 22(2), 1-19. Google Scholar, Crossref

Pine, J. (2012). The art of making do in Naples. Minneapolis, MN: University of Minnesota Press. Google Scholar, Crossref

Price, P., Ruud, A. E. (2010). (Eds.) Power and influence in South Asia: bosses, lords, and captains. Delhi: Routledge. Google Scholar

Quigley, D. (Ed.) (2005). The character of kingship. Oxford, UK: Berg. Google Scholar

Sahlins, M. (1963). Poor man, rich man, big man, chief: Political types in Melanesia and Polynesia. Comparative Studies in Society and History, 5(3), 285-303. Google Scholar, Crossref, ISI

Seal, G. (2009). The Robin Hood principle: Folklore, history, and the social bandit. Journal of Folklore Research, 46(1), 67-89. Google Scholar, Crossref, ISI

Sennett, R. (1980). Authority. London, UK: Faber and Faber. Google Scholar

Sidel, J. (1999). The usual suspects: Nardong Putik, Don Pepe Oyson, and Robin Hood. In Rafael, V. (Ed.), Figures of criminality in Indonesia, the Philippines, and Colonial Vietnam (Studies on Southeast Asia, No. 25, pp. 70-94). Ithaca, NY: Southeast Asia Program Publications, Cornel University Press. Google Scholar

Singh, R. (2016). The politics of Zilla Parishads: The case study of Saharanpur district (Master dissertation). Ashoka University. Google Scholar

Sircar, N. (2018). Money in elections. The role of personal wealth in elections outcomes. In Kapur, D., Vaishnav, M. (Eds), The cost of democracy. Political finance in India. New Delhi: Oxford University Press. Google Scholar

Vaishnav, M. (2017). When crime pays: Money and muscle in Indian politics. New Haven, CT: Yale University Press. Google Scholar

Verniers, G. (2014, June 7). The root of the Goonda Raj: Why there is so much violence in Uttar Pradesh. Scoll.in. Retrieved from http://scroll.in/article/666450/The-roots-of-GoondaRaj:-Why-there\%27s-so-much-violence-in-Uttar-Pradesh/ Google Scholar

Volkov, V. (2002). Violent entrepreneurs: The use of force in the making of Russian capitalism. Ithaca, NY: Cornell University Press. Google Scholar

Von Lampe, K., Johansen, P. O. (2003). Criminal networks and trust. Paper presented at the 3rd Annual Meeting of the European Society of Criminology (ESC) Helsinki, Finland, 29 August. Retrieved from http://www.organized-crime.de/criminalnetworkstrust.htm Google $\underline{\text { Scholar }}$

Weber, M. (1978). Politics as a vocation. In Runciman, W. G. (Ed.), (trans. Matthews, E. ) Weber: Selections in translation (pp. 212-225). Cambridge, UK: Cambridge University Press $\underline{\text { Google Scholar, Crossref }}$ 
Wilson, I. D. (2015). The politics of protection rackets in post new order Indonesia: Coercive capital, authority and street politics. London, UK: Routledge. Google Scholar, Crossref Witsoe, J. (2009). Territorial democracy: Caste, dominance and electoral practice in postcolonial India. Political and Legal Anthropology Review, 32(1), 64-83. Google Scholar, $\underline{\text { Crossref }}$ 